\title{
Enzymatic Properties of Phytase from Escherichia coli DH5a
}

\author{
Tao Wang \\ Jiangsu Key Construction Laboratory of Food Resource \\ Development and Quality Safe \\ Xuzhou Institute of Technology \\ Xuzhou, Jiangsu, 221008, China \\ wangtaohf@126.com
}

\section{Wen Li}

Jiangsu Key Construction Laboratory of Food Resource

Development and Quality Safe

Xuzhou Institute of Technology

Xuzhou, Jiangsu, 221008, China

wenlisony@126.com

\begin{abstract}
A Escherichia coli strain producing phytase named DH5 $\alpha$ was chosen from four $E$. coli stains, the enzyme activity was $17.88 \mathrm{U} / \mathrm{mL}$ after fermented at $37^{\circ} \mathrm{C}$ for 2 days. The enzymatic properties of crude enzyme solution were studied. The optimal temperature was $55^{\circ} \mathrm{C}$; optimal $\mathrm{pH}$ was 2.5 and 7.0, enzyme had certain resistance to heat and different $\mathrm{pH}$ conditions, $75 \%$ activity could be maintained when treated at $65^{\circ} \mathrm{C}$ for $30 \mathrm{~min}$, and $60 \%$ activity still remained when treated in the $\mathrm{pH}$ range of 2 to 9 for $30 \mathrm{~min}$ and $60 \mathrm{~min}$. Resistance to $\mathrm{KH}_{2} \mathrm{PO}_{4}$ of phytase was poor, low concentrations of $\mathrm{KH}_{2} \mathrm{PO}_{4}(15 \mathrm{mg} / \mathrm{L})$ could inhibit the enzyme activity to below $40 \%$; all kinds of metal ions had no significant activation or inhibition effect on enzyme, the enzyme had resistance to pepsin but no resistance to trypsin, after treated by trypsin for $30 \mathrm{~min}$, only $66.69 \%$ of the activity retained, while treated by pepsin, the activity could still maintain more than $90 \%$.
\end{abstract}

Keywords-Escherichia coli; Phytase; Enzymatic properties; Molybdenum blue method; Enzyme activity

\section{INTRODUCTION}

Phytase is a class of hydrolases which can hydrolyze phytic acid into phosphoric acid inositol, it exists widely in plant and animal tissues and microbial cells and mainly exists in seeds of the plant. Because of the different kinds of plants, the activity of phytase varies greatly[1-5]. Microbes are the most convenient and the most economical sources of phytase[6]. Bacteria, yeasts, fungi and many multicellular fungi can produce phytase but their properties are different[7]. According to the difference of the optimum $\mathrm{pH}$ values, Phytase can be divided into acidic phytase, neutral phytase and alkaline phytase. However, due to the microbial phytase has high activity and can be produced easily, the research and development on it are the most extensive and deepest[8-9].

\author{
Yao Hao \\ Jiangsu Key Construction Laboratory of Food Resource \\ Development and Quality Safe \\ Xuzhou Institute of Technology \\ Xuzhou, Jiangsu, 221008, China \\ 1742706438@qq.com
}

Yang Liu

Jiangsu Key Construction Laboratory of Food Resource Development and Quality Safe

Xuzhou Institute of Technology

Xuzhou, Jiangsu, 221008, China 741305270@qq.com

At present, phytase is widely used in food and feed industry, it can make the utilization ratio of phosphorus which exists $n$ plant feedstuffs increase by $60 \%$ and the amount of phosphorus in faeces reduce by $40 \%$, so that it can reduce the amount of phosphorus in the feed and the pollution to the environment. Besides, it can also damage the affinity of phytic acid, mineral elements and protein which contain in plant feedstuffs or food, improve the bioavailability of mineral elements and the digestible rate of protein, so as to improve the nutritional value of food and livestock production efficiency [10-12].

In this study, the enzymatic properties of phytase produced by $E$. coli DH5 $\alpha$ were examined. The objective of this study was to grasp the characteristics of phytase better and lay a good fundation for the application of phytase.

\section{MATERIALS AND METHODS}

\section{A. materials and reagents}

Escherichia coli DH5a, AB1157, GM2929, KK1, preserved in microbial genetics and breeding laboratory of Xuzhou Engineering Institute; Sodium phytate: High purity reagent, singma; Ammonium molybdate tetrahydrate: AR, Chemical reagent factory in hefei university of technology; Ammonium sulfate: AR, Tianjin Municipality kemi'ou Chemical Reagent Co. Ltd.; trichloroacetic acid (TDA): AR, Hedong district of tianjin red crag reagent factory; Other reagents are of analytic grade.

\section{B. Culture medium} 5.

1) $L B$ medium $\left(g \cdot L^{-1}\right)$ : beef extract 5 , peptone $10, \mathrm{NaCl}$

2) Fermentation medium $\left(g \cdot L^{-1}\right)$ : glucose 15 , peptone 3 , $\left(\mathrm{NH}_{4}\right)_{2} \mathrm{SO}_{4} 2, \mathrm{MgSO}_{4} \cdot 7 \mathrm{H}_{2} \mathrm{O} 2, \mathrm{KCl} 0.5, \mathrm{FeSO}_{4}$ 0.03, $\mathrm{MnSO}_{4} \cdot 7 \mathrm{H}_{2} \mathrm{O}$ 0.03, $\mathrm{pH} 7.0$. 


\section{Culture conditions}

1) Seed culture: Two rings of strain growing well in test tubes was inoculated into the $250 \mathrm{~mL}$ conical flask containing $100 \mathrm{~mL}$ of $\mathrm{LB}$ medium and cultured on a reciprocal shaker(120 rpm) for $1 \mathrm{~d}$ at $37^{\circ} \mathrm{C}$.

2) Fermentation culture: The seed culture was then inoculated to the $250 \mathrm{~mL}$ conical flask containing $50 \mathrm{~mL}$ fermentation medium, and fermented on a reciprocal shaker(120 rpm) for $2 \mathrm{~d}$ at $37^{\circ} \mathrm{C}$.

\section{The preparation of crude enzyme}

Cultures were centrifuged at $8000 \mathrm{r} \cdot \mathrm{min}^{-1}$ for 10 minutes at $4^{\circ} \mathrm{C}$ and the supernatant was used for the estimation of phytase activity.

\section{E. Determination of phytase activity}

Phytase activity was determined using the method described by Harland (1980) with slight modifications[13]. Definition of activity unit of enzyme: Under the condition of $37{ }^{\circ} \mathrm{C}$ temperature, $\mathrm{pH} 5.5,1 \mu \mathrm{mol}$ inorganic phosphorus is released from the $5.0 \mathrm{mmol} / \mathrm{L}$ sodium phytate solution per minute is a unit of phytase activity(U). The enzyme activity was calculated by the following equation (1):

$$
\text { Phytase activity }=\frac{\mathrm{C} \times \mathbf{F}}{\mathrm{V} \times 30}
$$

where $\mathrm{C}$ is the phosphorus concentration $(\mathrm{mol} / \mathrm{L}) ; \mathrm{F}$ is total diluted multiples of the sample solution before the reaction; $\mathrm{V}$ is sample volume $(\mathrm{mL}) ; 30$ is the reaction time.

\section{F. Enzymic properties of crude enzyme of $\mathrm{E}$. coli $\mathrm{DH} 5 \mathrm{\alpha}$}

1) The optimal pH of enzyme reaction: The enzyme activity of crude enzyme was determined as described above. The buffer used for $\mathrm{pH}$ measurement was 0.1 $\mathrm{mol} / \mathrm{L}$ acetic acid sodium-acetate buffer, $\mathrm{pH}$ was adjusted to $2.0,2.5,3.0,4.0,5.0,6.0,7.0,8.0$ and 9.0. The highest enzyme activity was set as $100 \%$, the ratio of enzyme activity under other conditions to the highest enzyme activity was relative enzyme activity.

2) $p H$ stability of enzyme: Enzyme solution was treated at different $\mathrm{pH}$ values $(2.0,2.5,3.0,4.0,5.0,6.0$, $7.0,6.0,7.0$ ) for $30 \mathrm{~min}$ and $60 \mathrm{~min}$ at $37^{\circ} \mathrm{C}$, then adjusted back to the optimal $\mathrm{pH}$ value. Enzyme activity was determined under routine conditions to investigate the $\mathrm{pH}$ stability of the enzyme at $37^{\circ} \mathrm{C}$.

3) The optimal temperature of enzyme reaction: The enzyme activity according to temperature was measured at different temperatures $\left(30^{\circ} \mathrm{C}, 35^{\circ} \mathrm{C}, 45^{\circ} \mathrm{C}\right.$, $55^{\circ} \mathrm{C}, 65^{\circ} \mathrm{C}, 75^{\circ} \mathrm{C}, 85^{\circ} \mathrm{C}$ ). Enzyme activity was determined at $37^{\circ} \mathrm{C}$.

4) Thermal stability of enzyme: Crude enzyme was treated at different temperatures $\left(35^{\circ} \mathrm{C}, 45^{\circ} \mathrm{C}, 55^{\circ} \mathrm{C}\right.$, $65^{\circ} \mathrm{C}, 75^{\circ} \mathrm{C}$ ) for $30 \mathrm{~min}$ and $60 \mathrm{~min}$, and then residual enzyme activity was determined at $37^{\circ} \mathrm{C}$.

5) Effect of metal ions on phytase activity: $0.1 \% \mathrm{AgCl}$, $\mathrm{AlCl}_{3}, \mathrm{CoCl}_{2}, \mathrm{CuSO}_{4}, \mathrm{FeSO}_{4}, \mathrm{NH}_{4} \mathrm{Cl}, \mathrm{KCl}, \mathrm{GeCl}_{4}, \mathrm{MnCl}_{2}$ was separately added to the buffer, then enzyme activity was determined under routine conditions.

6) Effect of $\mathrm{KH}_{2} \mathrm{PO}_{4}$ on phytase activity: Effect of $\mathrm{KH}_{2} \mathrm{PO}_{4}$ whose concentration was $1,5,7,10,15,20,30$,
$40,50,60 \mathrm{mg} / \mathrm{L}$ on phytase was investigated. Enzyme activity was determined under routine conditions.

7) Effects of pepsin and trypsin on phytase activity: $1 \mathrm{mg} / \mathrm{L}$ pepsin and trypsin was respectively added to crude enzyme liquid, treated for $10 \mathrm{~min}, 30 \mathrm{~min}, 60 \mathrm{~min}$ under the optimum temperature. Enzyme activity was determined under routine conditions.

\section{RESULTS AND DISCUSSION}

\section{A. $\mathrm{KH}_{2} \mathrm{PO}_{4}$ standard curve}

Phosphorus concentration was set as Abscissa, absorbance at $700 \mathrm{~nm}$ was set as ordinate, then standard curve was drawn, as shown in Fig. 1. linear regression equation is $\mathrm{y}=0.0026 \mathrm{x}-0.0024$, correlation coefficient $\mathrm{R}^{2}=0.9979$, showing a good linear relationship.

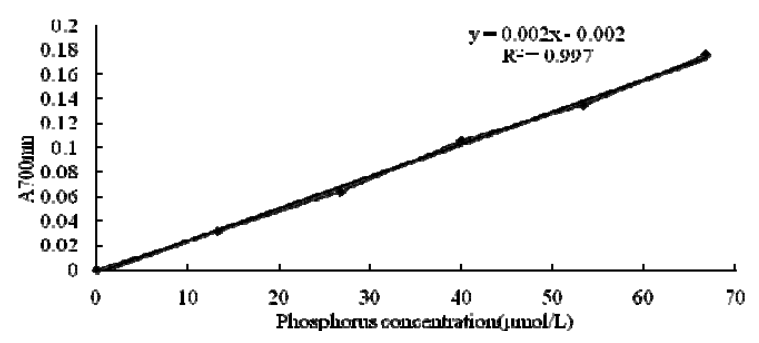

Figure 1. Standard curve of $\mathrm{KH}_{2} \mathrm{PO}_{4}$

\section{B. Selection of the best strain and medium}

Phytase activity of four strains of $E$. coli was determined every $24 \mathrm{~h}$, the results were shown in Table 1. As seen from table 1, in the two different culture medium, enzyme activity of phytase produced by DH5 $\alpha$ were the highest of the 4 strains, so DH5 $\alpha$ was the best strain to produce phytase. Meanwhile, it can be seen from the results of the experiment, phytase-producing activity of DH5 $\alpha$ was higher when cultured in fermentation medium, up to $17.88 \mathrm{U} / \mathrm{mL}$, so the optimum medium for phytase production was fermentation medium.

\section{TABLE 1 SELECTION OF THE BEST STRAIN}

\begin{tabular}{|c|c|c|c|c|c|}
\hline \multirow{2}{*}{$\begin{array}{c}\text { Kinds of } \\
\text { Culture } \\
\text { medium }\end{array}$} & $\begin{array}{c}\text { Time } \\
\text { (h) }\end{array}$ & \multicolumn{4}{|c|}{ Enzyme activity (U/mL) } \\
\cline { 3 - 6 } & & DH5a & AB1157 & GM2929 & KK1 \\
\hline \multirow{3}{*}{ LB medium } & 24 & $6.45 \pm 0.12 \mathrm{c}$ & $11.76 \pm 0.11 \mathrm{a}$ & $10.64 \pm 0.21 \mathrm{~b}$ & $4.06 \pm 0.16 \mathrm{~d}$ \\
\cline { 2 - 6 } & 48 & $12.55 \pm 0.21 \mathrm{a}$ & $9.77 \pm 0.22 \mathrm{c}$ & $11.89 \pm 0.05 \mathrm{~b}$ & $2.58 \pm 0.13 \mathrm{~d}$ \\
\cline { 2 - 6 } & 72 & $8.18 \pm 0.12 \mathrm{a}$ & $6.25 \pm 0.31 \mathrm{c}$ & $7.92 \pm 0.02 \mathrm{~b}$ & $0.98 \pm 0.09 \mathrm{~d}$ \\
\hline \multirow{2}{*}{$\begin{array}{c}\text { Fermentation } \\
\text { medium }\end{array}$} & 24 & $11.63 \pm 0.15 \mathrm{a}$ & $5.19 \pm 0.26 \mathrm{c}$ & $1.00 \pm 0.12 \mathrm{~d}$ & $9.19 \pm 0.11 \mathrm{~b}$ \\
\cline { 2 - 6 } & 48 & $17.88 \pm 0.22 \mathrm{a}$ & $5.61 \pm 0.42 \mathrm{~d}$ & $8.13 \pm 0.25 \mathrm{~b}$ & $6.41 \pm 0.05 \mathrm{c}$ \\
\cline { 2 - 6 } & 72 & $5.68 \pm 0.35 \mathrm{a}$ & $5.13 \pm 0.10 \mathrm{~b}$ & $4.84 \pm 0.24 \mathrm{c}$ & $4.49 \pm 0.12 \mathrm{~d}$ \\
\hline
\end{tabular}

Data expressed as mean \pm SD from triplicate experiments. different superscripts within the same row are significantly different $(\mathrm{P}<0.05)$

\section{Determination of incubation time}

Phytase activity that DH5 $\alpha$ produced was determined every 12 hours, the results were shown in Fig. 2. As seen in Fig. 2 , phytase activity of DH5 $\alpha$ reached the peak when cultured for $48 \mathrm{~h}$, when phytase activity was up to $17.92 \mathrm{U} / \mathrm{mL}$. After that, the phytase acitibity decreased. so the incubation time was $48 \mathrm{~h}$. 


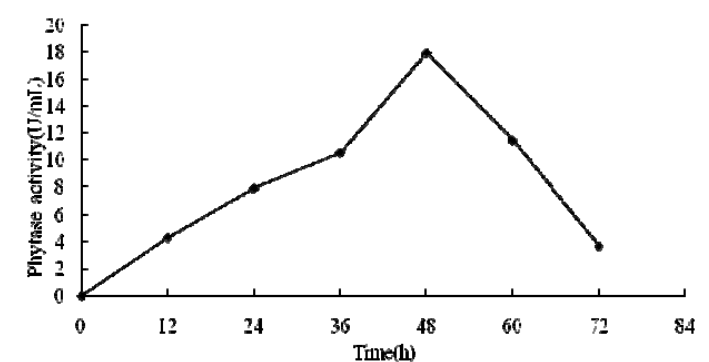

Figure 2. Effect of culture time on phytase activity

\section{Optimal $p H$ of enzyme reaction}

The activity of phytase was determined at different $\mathrm{pH}$ values ranged from 2 to 9, the results were shown in Fig. 3. As shown in Fig. 3, phytase produced by DH5 $\alpha$ reached the peak at $\mathrm{pH} 2.5$ and its relative enzyme activity was $100 \%$, then enzyme activity gradually decreased, but reached another peak at $\mathrm{pH} 7$, when relative enzyme activity was $61 \%$. After that, the enzyme activity gradually declined, so enzyme activity was higher both at pH 2.5 and pH 7, it had certain adaptability to acidic and neutral conditions and had the characteristics of both acidic phytase and neutral phytase. So it would have a good application prospect.

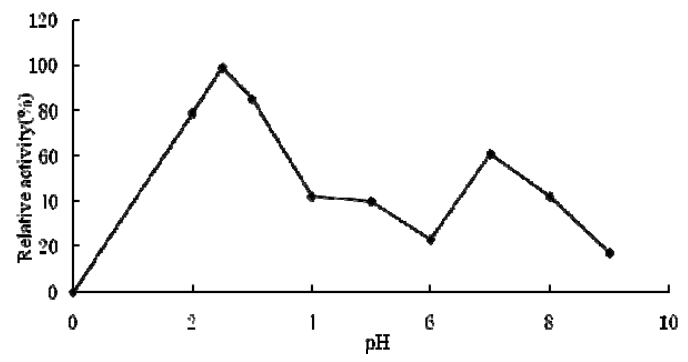

Figure 3. Effect of $\mathrm{pH}$ on phytase activity

\section{E. pH stability of phytase}

To measure $\mathrm{pH}$ stability, the remaining phytase activity was determined after incubation at various $\mathrm{pHs}$ for $30 \mathrm{~min}$ and $60 \mathrm{~min}$ at $37^{\circ} \mathrm{C}$ The results were shown in Fig.4. The enzyme was more stable in the $\mathrm{pH}$ range of 2.55.0 , with more than $80 \%$ of the initial activity remained. The enzyme could always keep the activity of about $60 \%$ at different $\mathrm{pHs}$, it showed that the phytase had good $\mathrm{pH}$ stability. The phytase could maintain the activity of more than $70 \%$ in the $\mathrm{pH}$ range of $2-5$, which showed that it had strong resistance to acid; the phytase could maintain the activity of more than $60 \%$ in the $\mathrm{pH}$ range of $6 \sim 9$, which showed that it also had good stability under neutral $\mathrm{pH}$ condition. It was concluded that the enzyme had higher resistance to $\mathrm{pH}$ and it had certain application prospect.

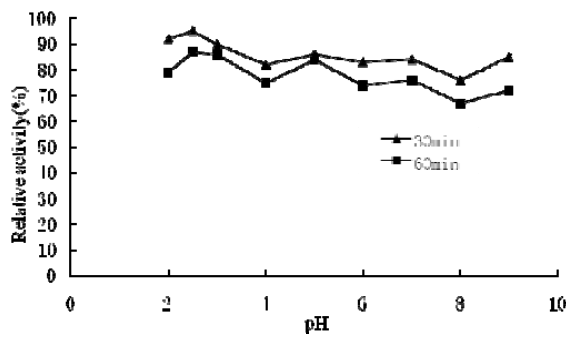

Figure 4. pH stability of phytase

\section{F. Optimal temperature of enzyme reaction}

The effect of temperature on phytase activity was detected, the results were shown in Fig.5. The relative enzyme activity of phytase increased firstly, enzyme activity was higher from $30^{\circ} \mathrm{C}$ to $55^{\circ} \mathrm{C}$,maximum activity was exhibited at $55^{\circ} \mathrm{C}$, then the activity of the enzyme decreased rapidly when temperature was higher than $55^{\circ} \mathrm{C}$. When the temperature was above $80^{\circ} \mathrm{C}$, the enzyme lost activity completely., the result would have a certain guide significance to the application in the future.

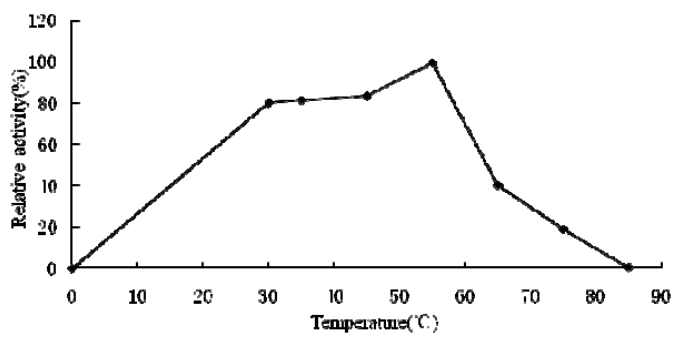

Figure 5. Effect of temperature on phytase activity

\section{G. Thermal stability of phytase}

The thermal stability of phytase was measured by incubating the enzyme at various temperatures for $30 \mathrm{~min}$ and $60 \mathrm{~min}$, the residual enzyme activity was determined. The results were shown in Fig.6. Phytase activity could still remain around $75 \%$ after incubated for 30 min and 60 min below $65^{\circ} \mathrm{C}$, then the enzyme activity reduced quickly and could just stay around $30 \%$ at $75^{\circ} \mathrm{C}$. Prolonging the time did not much affect the thermal stability. It could be concluded that the enzyme had certain thermal stability.

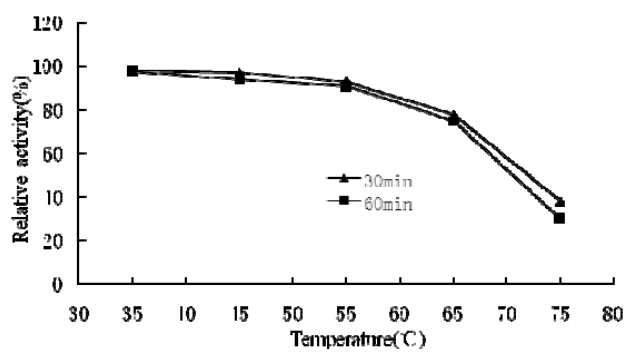

Figure 6 . Thermal stability of phytase

\section{H. Effect of metal ion on phytase activity}

Effect of metal ion on phytase activity was measured, the results were shown in Table 2. No significant inhibition was observed in the presence of all kinds of metal ions listed in Table 2. So the enzyme had certain resistance to metal ions. In the presence of the metal ions, all of the relative phytase activity measured could keep high. As a consequence, phytase was not sensitive to metal ions. The results provided reference for its future use in the feed industry. 
TABLE 2 EffECT OF METAL ION ON PHYTASE

\begin{tabular}{cc}
\multicolumn{2}{c}{ ACTIVITY } \\
\hline $\begin{array}{c}\text { Metal } \\
\text { ions }\end{array}$ & $\begin{array}{c}\text { Relative enzyme } \\
\text { activity } / \%\end{array}$ \\
\hline $\begin{array}{c}\text { None } \\
\mathrm{Fe}^{2+}\end{array}$ & $100.00 \pm 0.17 \mathrm{a}$ \\
$\mathrm{K}^{+}$ & $99.41 \pm 0.71 \mathrm{ab}$ \\
$\mathrm{Al}^{3+}$ & $99.95 \pm 0.65 \mathrm{bc}$ \\
$\mathrm{Cu}^{2+}$ & $98.88 \pm 0.48 \mathrm{ab}$ \\
$\mathrm{Co}^{2+}$ & $99.39 \pm 0.61 \mathrm{abc}$ \\
$\mathrm{NH}_{4}^{+}$ & $99.25 \pm 0.78 \mathrm{bc}$ \\
$\mathrm{Ag}^{+}$ & $99.09 \pm 0.25 \mathrm{bc}$ \\
$\mathrm{Mn}^{2+}$ & $98.51 \pm 0.39 \mathrm{~cd}$ \\
$\mathrm{Ge}^{4+}$ & $97.82 \pm 0.41 \mathrm{~d}$ \\
\hline
\end{tabular}

Data expressed as mean \pm SD from triplicate experiments. different superscripts within the same column are significantly different $(\mathrm{P}<0.05)$

\section{Effect of $\mathrm{KH}_{2} \mathrm{PO}_{4}$ on phytase activity}

Different concentrations of $\mathrm{KH}_{2} \mathrm{PO}_{4}$ solution $(1,5,7$, $10,15,20,30,40,50,60 \mathrm{mg} / \mathrm{L})$ was added to the crude enzyme, enzyme activity was determined under routine conditions. The results were shown in Fig.7. As seen from the Figure, $\mathrm{KH}_{2} \mathrm{PO}_{4}$ solution with lower concentrations had significant inhibitory effect on phytase activity, when the concentration was over $15 \mathrm{mg} / \mathrm{L}$, the remaing activity of the enzyme was less than $40 \%$; When the concentration reached $60 \mathrm{mg} / \mathrm{L}$, the enzyme almost lost activity. So in the process of application, the effect of element phosphorus on phytase activity should be avoided and the conditions during the use of the procedure should be controlled.

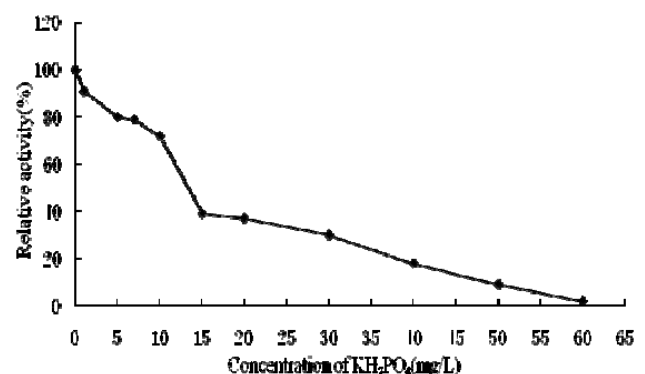

Figure 7. Effect of $\mathrm{KH}_{2} \mathrm{PO}_{4}$ concentration on phytase activity

\section{J. Effect of pepsin and trypsin on phytase activity}

$1 \mathrm{mg} / \mathrm{L}$ of pepsin and trypsin solution was added to the crude enzyme for $10 \mathrm{~min}, 30 \mathrm{~min}, 60 \mathrm{~min}$, then the phytase activity was determined. The results were shown in Table 3. The results showed that pepsin had no obvious inhibition or activation effect on the enzyme. On the contrary, trypsin had obvious inhibition effect on the enzyme. Thus it could be inferred that when the enzyme was added in animal feed, it would be more stable in the animal stomach than in the intestines.
TABLE 3 EFFECT OF PEPSIN AND TRYPSIN ON PHYTASE ACTIVITY

\begin{tabular}{ccc}
\hline Time/min & $\begin{array}{c}\text { Relative enzyme activity } \\
\text { after } \\
\text { treated by pepsin/\% }\end{array}$ & $\begin{array}{c}\text { Relative enzyme } \\
\text { activity } \\
\text { after treated by } \\
\text { trypsin/\% }\end{array}$ \\
\hline 0 & $100 \pm 0.10 \mathrm{a}$ & $100 \pm 0.09 \mathrm{a}$ \\
10 & $99.23 \pm 0.45 \mathrm{~b}$ & $84.19 \pm 0.15 \mathrm{~b}$ \\
20 & $98.09 \pm 0.35 \mathrm{c}$ & $75.48 \pm 0.23 \mathrm{c}$ \\
30 & $96.25 \pm 0.46 \mathrm{~d}$ & $66.69 \pm 0.38 \mathrm{~d}$ \\
\hline \multicolumn{3}{c}{ Data expressed as mean \pm SD from triplicate } \\
experiments. different superscripts within the same column \\
are significantly different $(\mathrm{P}<0.05)$
\end{tabular}

\section{Conclusions}

Four strains were cultured in different mediums, the phytase activity of the strains was determined, DH5a produced the highest enzyme activity in the fermentation medium. The phytase enzyme properties of crude enzyme from $\mathrm{DH} 5 \alpha$ were studied. The optimal $\mathrm{pH}$ of phytase was 2.5 and 7, this enzyme had certain stability under the condition of acidic and neutral $\mathrm{pH}$; the optimal temperature of enzyme was $55^{\circ} \mathrm{C}$. In the aspect of heat resistance, the enzyme activity could still keep $75 \%$ after incubated at $65^{\circ} \mathrm{C}$ for $30 \mathrm{~min}$, then the enzyme activity reduced quickly and it could just remain $30 \%$ at $75^{\circ} \mathrm{C}$. Metal irons had no obvious inhibition or activation effect on phytase activity but $\mathrm{KH}_{2} \mathrm{PO}_{4}$ solution in low concentration had obvious inhibition on phytase activity. Pepsin had no obvious inhibition or activation effect on the enzyme, on the contrary, trypsin had obvious inhibition effect on this enzyme.

Based on the study, we could conclude that the enzyme had certain advantages to resist different $\mathrm{pH}$ values. The enzyme had higher activity under the acidic and neutral conditions, which showed that phytase from E.Coli $\mathrm{DH} 5 \alpha$ had advantage compared with other phytase studied before. The phytase had good resistance to various metal ions, so it had a wide application prospect. Meanwhile, the phytase had better resistance to pepsin, so when it was added to the feed, phytic acid could be decomposed effectively and the absorption of nutrients could be improved.

In this study, the phytase was extracted from E. coli in nature, so some enzymatic properties were not very good, such as thermal stability, which could be improved by mutation or genetic engineering methods, so as to make it meet the requirements of industrial production.

\section{ACKNOWLEDGMENT}

This work was funded by National Natural Science Foundation of China (No. 81273004), Qing Lan Projec, the Open Project Program of Jiangsu Key Laboratory of Food Resource Development and Quality Safety, Xuzhou Institute of Technology ( No.SPKF201412.) , National Training Programs of Innovation and Entrepreneurship for Undergraduates(201311998023)and Science and Technology Planning Project of Xuzhou (XF13C034) 


\section{REFERENCES}

[1] Chen W, Ye L, Guo F, et al. Enhanced activity of an alkaline phytase from Bacillus subtilis 168 in acidic and neutral environments by directed evolution[J]. Biochemical Engineering Journal, 2015, 98: 137-143.

[2] Gaind S, Singh S. Production, purification and characterization of neutral phytase from thermotolerant Aspergillus flavus ITCC $6720[\mathrm{~J}]$. International Biodeterioration \& Biodegradation, 2015, 99: $15-22$.

[3] Bala A, Jain J, Kumari A, et al. Production of an extracellular phytase from a thermophilic mould Humicola nigrescens in solid state fermentation and its application in dephytinization[J]. Biocatalysis and Agricultural Biotechnology, 2014, 3(4): 259-264.

[4] Kim Y O, Lee J K, Oh B C, et al. High-level expression of a recombinant thermostable phytase in Bacillus subtilis $[\mathrm{J}]$. Bioscience, biotechnology, and biochemistry, 1999, 63(12): 22052207.

[5] Kerovuo J, Lauraeus $M$, Nurminen $P$, et al. Isolation, characterization, molecular gene cloning, and sequencing of a novel phytase from Bacillus subtilis[J]. Applied and Environmental Microbiology, 1998, 64(6): 2079-2085.

[6] Yoon S J, Choi Y J, Min H K, et al. Isolation and identification of phytase-producing bacterium, Enterobacter sp. 4, and enzymatic properties of phytase enzyme[J]. Enzyme and microbial technology, 1996, 18(6): 449-454.
[7] Mullaney E J, Ullah A H J. The term phytase comprises several different classes of enzymes[J]. Biochemical and biophysical research communications, 2003, 312(1): 179-184.

[8] Huang H, Shi P, Wang Y, et al. Diversity of beta-propeller phytase genes in the intestinal contents of grass carp provides insight into the release of major phosphorus from phytate in nature[J]. Applied and environmental microbiology, 2009, 75(6): 1508-1516.

[9] Phillippy B Q, Wyatt C J. Degradation of phytate in foods by phytases in fruit and vegetable extracts[J]. Journal of food science, 2001, 66(4): 535-539.

[10] Liu N, Ru Y J, Li F D, et al. Effect of diet containing phytate and phytase on the activity and messenger ribonucleic acid expression of carbohydrase and transporter in chickens[J]. Journal of animal science, 2008, 86(12): 3432-3439.

[11] Wyss M, Pasamontes L, Friedlein A, et al. Biophysical characterization of fungal phytases (myo-inositol hexakisphosphate phosphohydrolases): molecular size, glycosylation pattern, and engineering of proteolytic resistance[J]. Applied and Environmental Microbiology, 1999, 65(2): 359-366.

[12] Laboure A M, Gagnon J, Lescure A M. Purification and characterization of a phytase (myo-inositol-hexakisphosphate phosphohydrolase) accumulated in maize (Zea mays) seedlings during germination[J]. Biochem. J, 1993, 295: 413-419.

[13] Harland B F, Harland J. (1980). Fmermentative reduction of phytase in rye, white, and whole wheat breads $[\mathrm{J}]$. Cereal Chemistry, $\quad 1980,57(3)$ : $\quad 226 \quad-\quad 229$ 